УДК $692+644.1$

\title{
ЕНЕРГОЕФЕКТИВНІ ТЕПЛОНАСОСНІ ТЕХНОЛОГІЇ. СТАН ТА ПЕРСПЕКТИВИ ЇХ ВПРОВАДЖЕННЯ В УКРАЇНІ
}

\author{
Снєжкін Ю.Ф., член - кореспондент НАН України \\ Інститут технічної теплофізики НАН України, вул. Желябова, 2а, Київ, 03057, Україна
}

В роботі розглядаються питання стану, розвитку і впровадження теплонасосних технологій в Україні. Наведено приклади використання цих технологій як в світі, так і в Україні. Представлені різні схеми використання теплонасосних технологій в коммунальному господарстві і промисловості. Показані можливі об'єми економії енергоресурсів при широкому вровадженні теплонасосних технологій.
В работе рассмотрены вопросы состояния, развития и внедрения теплонасосных технологий в Украине. Приведены примеры использования этих технологий как в мире, так и в Украине. Представлены различные схемы применения теплонасосных технологий в коммунальном хозяйстве и промышленности. Показаны возможные обьёмы экономии энергоресурсов при широком внедрении теплонасосных технологий.
In the article addresses issues the state, development and implementation of heat pump technology in Ukraine. Examples use of these technologies both in the world and in Ukraine. Presented various schemes using of heat pump technology in field of housing economy and industry. Shown volume are possible economy of power resources in a wide implementation of heat pump technology.

Бібл. 7, рис. 8 .

Ключові слова: теплонасосні технології, енергоефективність, відновлювані джерела енергії, заміщення природного газу, сушка.

\section{Bcmyn}

Україні, яка відноситься до країн з обмеженими власними енергоресурсами і імпортує близько 90 \% рідких та газоподібних енергоносіїв, притаманна надмірна енергоємність основних галузей промисловості (металургії, хімії, машинобудування, переробного та агропромислового комплексу, будіндустрії та комунального господарства).

Енергоємність внутрішнього валового продукту (ВВП) в Україні значно вища ніж в розвинутих країнах світу. Тому стратегічним напрямком розвитку країни $\epsilon$ скорочення енергоємності ВВП у рази і досягнення рівня споживання енергоносіїв 0,3 ...0,5 кг у. п. на 1 гривню ВВП [1].

Досягти цього можливо тільки структурною перебудовою промисловості, удосконаленням керування виробництвом за рахунок автоматизації та оптимізації технологічних процесів, оновленням і модернізацією теплоенергетичного обладнання 3 метою зниження питомих витрат палива, більш широким використанням альтернативних видів палива та відновлюваних джерел енергії.

У 2013 р. Кабінет Міністрів України прийняв Державну програму модернізації систем теплопостачання на 2014-2015 р.p., головною метою якої було зниження обсягів використання природного газу майже на 4,2 млрд. м ${ }^{3}$ на рік. Програма мала два напрями: модернізація обладнання і застосування альтернативних видів палива та відновлюваних джерел енергії. Особливістю цієї програми $\epsilon$ те, що вона створена на основі регіональних програм, які були розроблені кожною областю України, тобто там закладені реальні дані. Одним з аспектів цієї Програми було широке впровад- ження теплових насосів (ТН) в системах теплозабезпечення.

\section{Аналіз досліджень і публікацій}

Аналіз представлених даних цієї програми показав (рис. 1), що шляхом модернізації обладнання можливо заощадити 2,131 млрд. $\mathrm{M}^{3}$ на рік природного газу, або $25,4 \%$ річного споживання галузі. Найбільший показник економії дає заміна тепломереж - понад 1 млрд. м ${ }^{3}$ газу. Найменше - заміна котлів.

Використання альтернативних видів палива i відновлюваних джерел енергії заміщує 2,039 млрд. $\mathrm{M}^{3} /$ рік газу, або $24,2 \%$ його річного споживання в галузі. Найбільший показник заміщення газу дають теплові насоси - понад 0,9 млрд. м ${ }^{3} /$ рік. Найменший використання сонячної енергії.

Обсяг капіталовкладень на модернізацію обладнання становить 18,8 млрд. грн., або $68 \%$ фінансування програми (рис. 2). Найбільші витрати припадають на заміну тепломереж - 10,53 млрд. грн. (56 \% фінансів напрямку). В модернізацію котлів закладено найменше капіталовкладень - 4 \% всіх капіталовкладень в напрям. По другому напрямку капіталовкладення склали 9,06 млрд. грн., або 32\% фінансування всієї програми. Найбільші капіталовкладення припадають на роботи по теплопостачанню за рахунок використання електричної енергії - 2,8 млрд. грн. та теплових насосів - 2,7 млрд. грн. (30 \% фінансів напряму). Найменше капіталовкладень припадає на переобладнання котелень на тверде паливо - 8 \% від капіталовкладень напрямку.

Підрахунки ефективності капіталовкладень показують (рис. 3), що найменша вартість зекономленого газу буде при впровадженні теплоутилізаторів - 150 доларів 
США за 1000 м $^{3}$ газу, а найбільша - при впровадженні блочно-модульних котелень - 8325 доларів США за $1000 \mathrm{~m}^{3}$ газу. При заміні тепломереж вартість зекономленого газу становить 1300 доларів США за 1000 м³ газу.

По другому напрямку найменша вартість заміщеного газу досягається при впровадженні котлів на

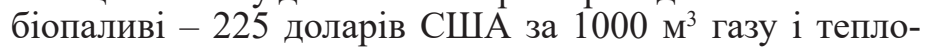

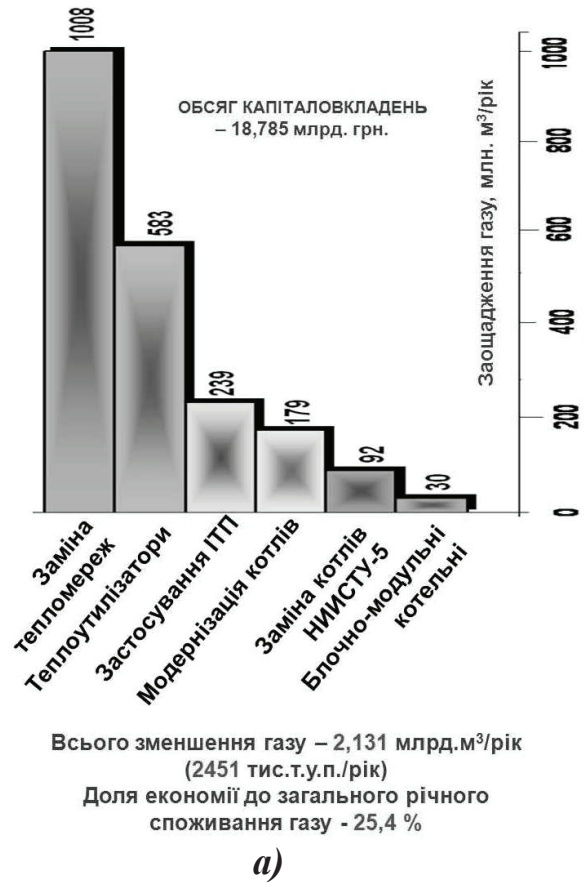

вих насосів - 362 доларів США за 1000 м газу. Найбільша - при використанні сонячної енергії 812 доларів США за 1000 м $^{3}$ газу.

Таким чином аналіз Державної програми показує, що найбільш ефективним засобом заощадження природного газу є впровадження теплових насосів в системи теплопостачання.

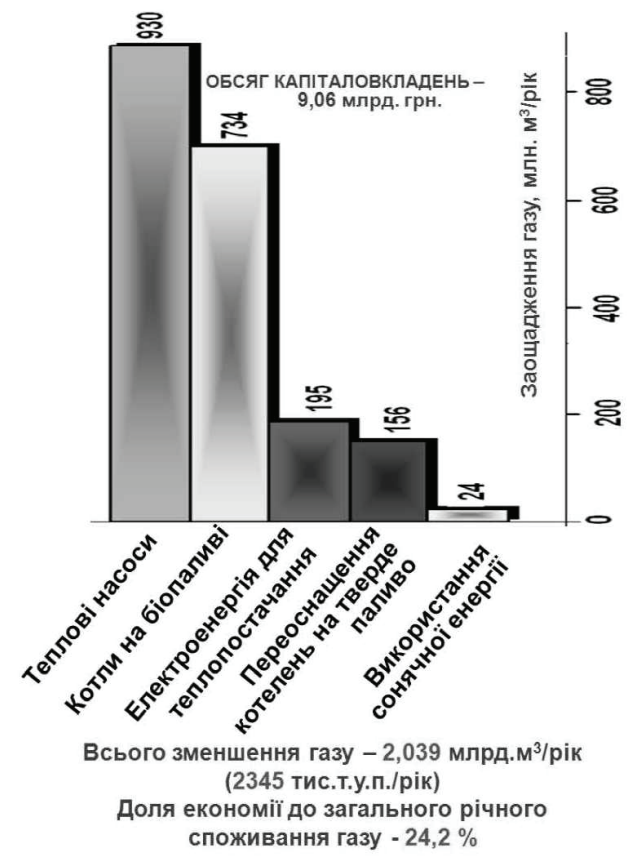

б)

Рис. 1. Дані програми модернізації систем теплопостачання Украӥни: а-модернізація обладнання; б - альтернативні види палива.

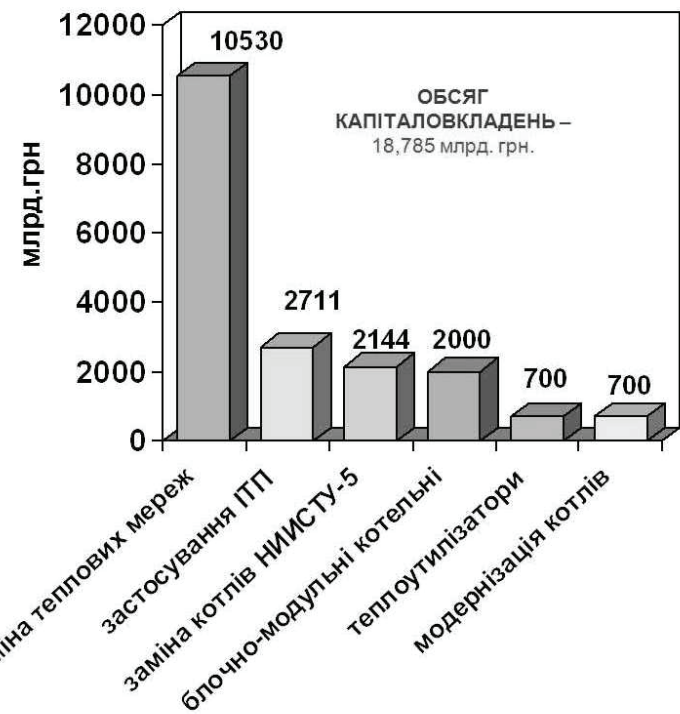

a)

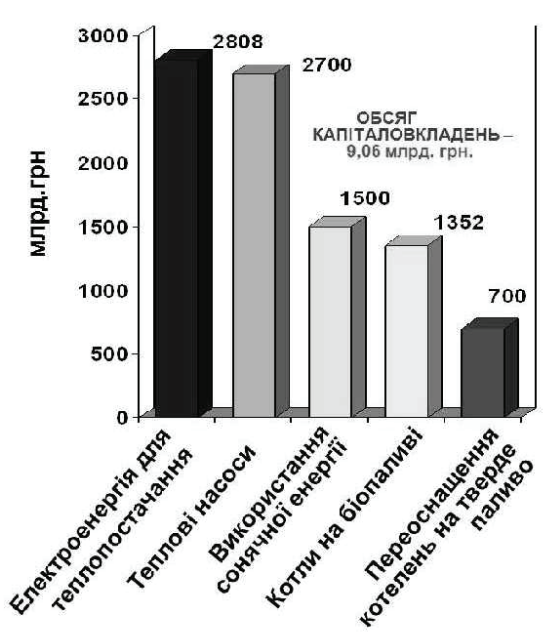

б)

Рис. 2. Капіталовкладення при впровадженні заходів програми:

а-на модернізацію обладнання; б - на заміщення газу альтернативними видами палива. 


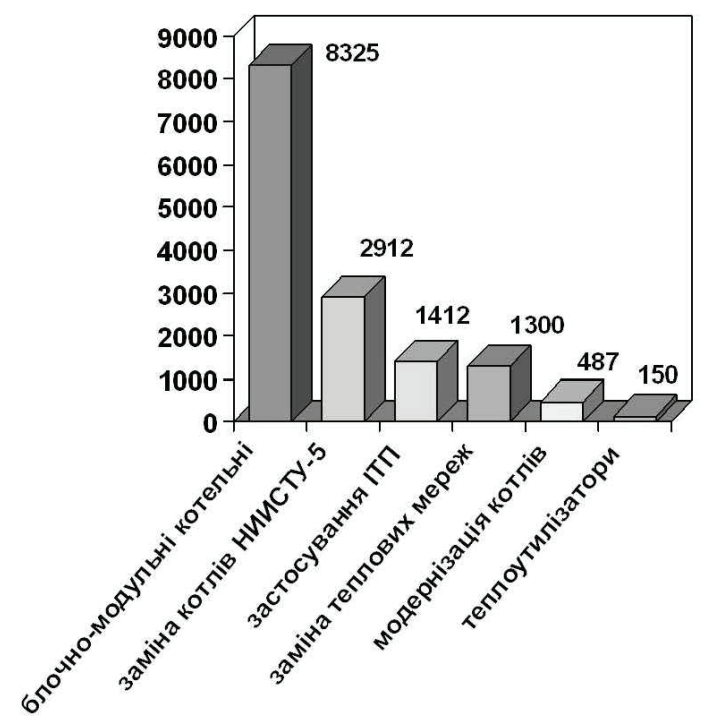

a)

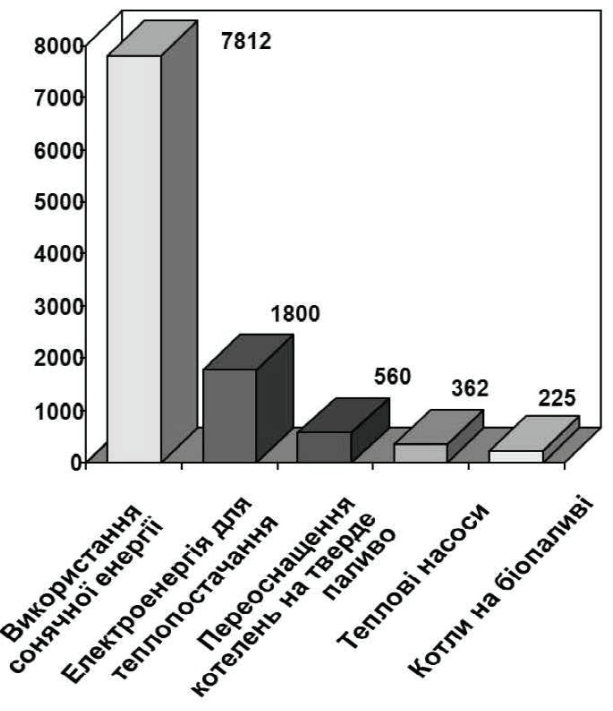

б)

Рис. 3. Капіталовкладення на $1000 \mathrm{M}^{3}$ зекономленого газу при впровадженні: а-модернізації обладнання; б - заміщення газу альтернативними видами палива.

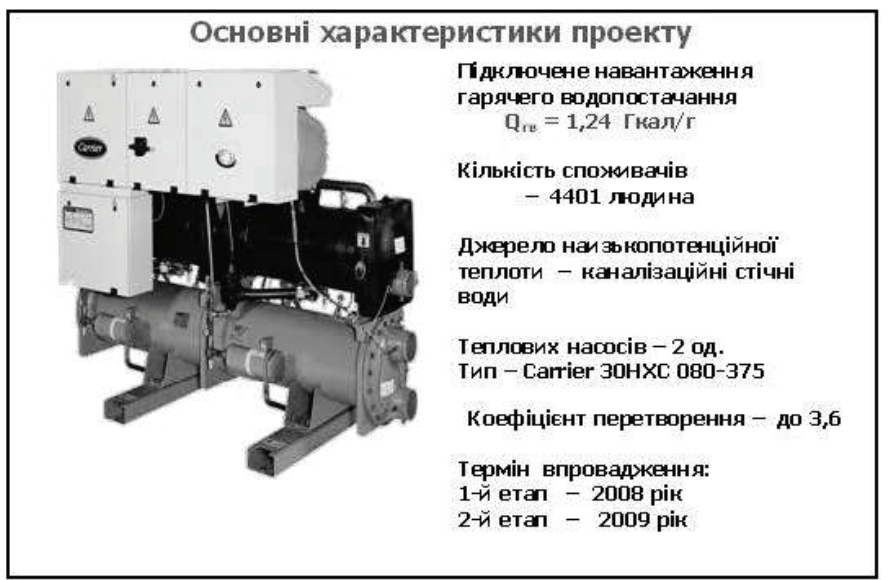

Рис. 4. Теплонасосна система гарячого водопостачання потужністю 1,5 кВт ум. Краматорськ.
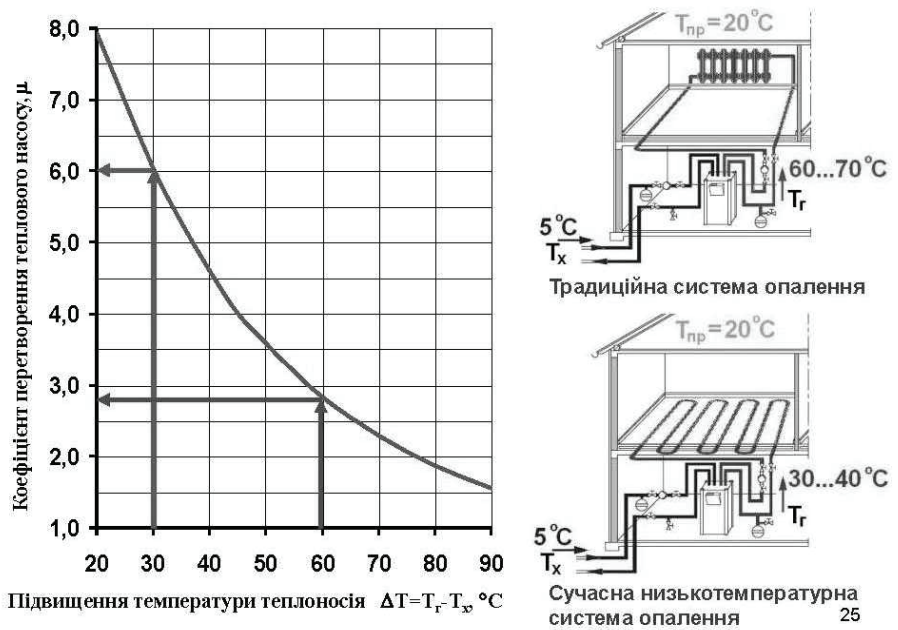

Рис. 5. Ефективність теплових насосів в різних системах опалення. 
Отримані результати підтверджуються і світовими даними по широкому використанню ТН. Наприклад, у Швеції за допомогою теплових насосів виробляється більше 50 \% тепла для потреб опалення і гарячого водопостачання, причому собівартість виробленої при цьому теплоти є на 20\% нижчою у порівнянні з ії виробництвом в традиційних газових котельнях. За прогнозами Світового енергетичного комітету, до 2020 р. частка теплонасосних установок у теплопостачанні зросте до $75 \%$ [2]. Найбільшою теплонасосною системою теплопостачання є Стокгольмська установка потужністю 320 МВт. Вона розміщена на причалених до берега баржах і використовує як низькотемпературне джерело воду Балтійського моря з температурою $2 \ldots 4^{\circ} \mathrm{C}$. Високі темпи впровадження ТН сьогодні відмічаються у всьому світі.

Які ж джерела низькопотенційної енергії можуть бути перспективними для України? На наш погляд, майже всі. Однак у великих містах найбільш ефективним $\epsilon$ використання теплоти стічних вод. Економічно доцільний потенціал теплоти стічних вод в Україні становить понад 1,5 млн. т у. п. на рік [3]. За нашими оцінками, при такому використанні ТН можна виробляти теплової енергії більш як 2 млн. т у. п. на рік, що дозволить замістити 2,2 млрд. м³ газу.

Об'єм каналізаційних стоків, що виробляються в м. Києві, практично не змінюється протягом року і складає 1,4 млн. м $^{3}$ на добу. Температура стічних вод нижча температури зовнішнього повітря в літній період і вища в зимовий. Так в січні вона складає $+18 \ldots+20^{\circ} \mathrm{C}$. За оцінками фахівців в міські комунікації разом зі стічними водами скидається близько 40 \% використаного тепла. Це робить їх ідеальним джерелом низькопотенційного тепла для використання в ТН. Крім того, значна частина населення м. Києва забезпечується артезіанською водою, яка має в середньому температуру $+12 \ldots+14{ }^{\circ} \mathrm{C}$, що також являє собою перспективне джерело низькопотенційного тепла для ТН.

Інститут технічної теплофізики НАН України вперше в Україні розробив і впровадив в м. Краматорську теплонасосну систему гарячого водопостачання потужністю 1,5 МВт, у якій джерелом низькопотенційної енергії $є$ каналізаційні стічні води (рис. 4). Ця теплонасосна установка забезпечує гарячою водою 4400 споживачів і дає змогу економити 1,56 млн. ${ }^{3}$ газу на рік.

Однак парадокс полягає в тому, що в умовах чинних пільгових тарифів на теплову енергію для населення розрахунковий термін окупності такої теплонасосної системи становить 19,5 років, а з урахуванням ринкової ціни зекономленого газу - лише 2,5 роки.

Економічно доцільний енергетичний потенціал грунту і грунтових вод в Україні оцінюється у понад 1,2 млн. т у. П. на рік 3]. Технічно можливі обсяги використання цієї енергії для теплозабезпечення за допомогою теплових насосів становлять 1,75 млн. т у. п. на рік, що дозволить заощадити близько 2 млрд. $\mathrm{m}^{3}$ газу. Інститут розробив компресійний тепловий насос типу «водавода» потужністю 50 і 100 кВт. Цю розробку впровадже- но в ДП НВК «Прогрес» у м. Ніжин, де в якості джерела енергії використовується низькопотенційна теплота артезіанської води.

Технічно-доцільний енергетичний потенціал повітря становить в Україні близько 3,5 млн. т у. п. на рік [4]. На сьогодні це $\epsilon$ найефективнішим джерелом низькопотенційної енергії. За даними Європейської асоціації ТН (ЕНРА), у 2008 р. частка ТН типу «повітрявода» для опалення в загальному обсязі продажів у восьми європейських країнах (Австрія, Італія, Німеччина, Норвегія, Фінляндія, Франція, Швейцарія, Швеція) становила $34,9 \%$, що майже в 4 рази перевищує продажі грунтових ТН. Це пояснюється насамперед тим, що технічні характеристики насосів типу «повітря-вода» $\epsilon$ досить високими (шведські ТН фірми «Octopus» гарантовано працюють навіть при $\left.-40^{\circ} \mathrm{C}\right)$, а капітальні витрати на їх впровадження $є$ суттєво меншими у порівнянні 3 грунтовими [6].

В останні роки Інститут впровадив 4 теплонасосні установки потужністю від 0,6 до 1,5 МВт, розробив 17 техніко-економічних обгрунтувань на опалення та гаряче водопостачання різного роду приміщень та будівель. Термін окупності об'єктів, якщо розраховувати його за економією природного газу, становить $2 . .4$ роки.

Ефективність використання ТН у різних системах опалення наведено на рис. 5. У будівлях, обладнаних традиційними батареями, коефіцієнт перетворення енергії теплонасоса не перевищує значення 3,0 , а в разі використання низькотемпературної системи опалення типу «тепла підлога» він зростає більш ніж удвічі.

Для широкого впровадження теплонасосних установок необхідна політика їх державного стимулювання. Так, у країнах $\mathrm{CC}$ за останні роки прийнято цілу низку законів, що сприяють розвитку цього напряму [5]. До них належать:

1. Диференціація субсидій за такими критеріями: нова чи стара будівля; житлові чи нежитлові приміщення; грунтовий чи повітряний ТН; величина коефіцієнта перетворення енергії при впровадженні теплового насосу.

2. Закон щодо нових будинків з обов'язковим забезпеченням 50 \% їх потреб у тепловій енергії за рахунок альтернативних джерел енергії (Німеччина).

3. Надання субсидії при встановленні ТН: в новому будинку - $10 €$ на 1 м $^{2}$ житлової площі (максимум $2000 €)$, відшкодування $10 \%$ інвестиційних витрат; у будинку після реконструкції - $30 €$ на 1 м $^{2}$ житлової площі (максимум $3000 €$ ), відшкодування до $15 \%$ інвестиційних витрат (Німеччина).

4. Субсидія в розмірі $30 \%$ витрат на встановлення (постачання і монтаж) ТН (максимум $3300 €$ ) за умови, що споживання електроенергії зросте не більш як на $35 \%$ (Швеція).

5. У новобудовах надання субсидії $2200 €$, якщо сезонний коефіцієнт перетворення енергії $\mu \geq 4,5$ (4,3 з підігріванням води), і $1500 €$, якщо $\mu \geq 3,8$ (3,6 3 підігріванням води). У будівлях після реконструкції субсидія збільшується на $220 €$, але лише у разі заміни застарілих котлів, віком понад 15 років (Австрія).

6. Податкові пільги у розмірі $25 \ldots .50 \%$ при 
встановленні ТН (Франція).

Ефективність використання ТН великою мірою залежить від співвідношення цін на електричну та теплову енергію. Порівняння вартості енергетичної складової теплоти, виробленої за допомогою компресійної теплонасосної установки 3 коефіцієнтом перетворення енергії $3,0 \ldots 4,5$ та при спалюванні газу в традиційній котельні, показує, що в разі ціни на газ понад 5 тис. грн. за 1 тис. м $^{3}$, а на електроенергію $1,0 \ldots 1,22$ грн. за кВт. год альтернативи використанню ТН немає (рис. 6).

3 огляду на перспективи впровадження ТН у системах теплозабезпечення та гарячого водопостачання, розрахунки показують, що технічно досяжний потенціал енергозбереження може становити 26,5 млн. т у. п. на рік, що в свою чергу дозволить заощадити до 20 млрд. м газу (рис. 7).

Як відомо, для одержання 1 кВт·год теплової енергії за допомогою теплового насоса потрібно витратити $0,3 \ldots 0,4$ кВт·год електричної енергії. Виходить, що для отримання теплоти, еквівалентної 20 млрд. ${ }^{3}$ газу (148,8 млрд. кВт год в електричному еквіваленті), необхідно витратити 51,3 млрд. кВт.год. електричної енергії, що становить 26,5 \% електроенергії, виробленої в Україні в 2013 році. Населення й комунально-побутові споживачі в 2013 р. спожили 40,7 \% від усієї виробленої електроенергії. Отже, використання цього потенціалу в повному обсязі в Україні теоретично можливе, а практично - на сьогодні навряд чи може бути досягнено.

Як же вирішити цю проблему? Одним із шляхів може бути вирівнювання нічного «провалу» в електрозабезпеченні для виробництва й акумулювання теплової енергії з ії використанням у денний час за допомогою теплонасосних установок (8000 МВт за добу взимку і $5000 \mathrm{MBт}$ - влітку). Найефективніше теплові насоси працюють з акумуляторами теплоти й двотарифними лічильниками, використовуючи електроенергію в період нічного «провалу» добового графіка електронавантаження в системі. При цьому є вигода як для користувачів теплоти з ТН через зниження плати за електроенергію за нічним тарифом, так і для енергосистеми. Завдяки акумулювання теплоти собівартість 1 Гкал теплоти знижується на $15 . .20 \%$.

Крім того, Україна має резерв потужностей з виробництва електроенергії. За розрахунками фахівців ІТТФ НАН України, за допомогою вдосконалення роботи енергосистеми України $\mathrm{i}$ «форсування» атомної та теплової енергії можна додатково отримати 21,6 млрд. кВт·год. електроенергії. Якщо цю електроенергію використати на привод ТН, то ми одержимо 62,6 млрд. кВт·год теплоти, що відповідає заміщенню 8,4 млрд. м³ газу. Це $\epsilon$ технічно досяжним потенціалом енергозбереження в Україні при впровадженні ТН.

Державною програмою модернізації систем теплопостачання заплановано впровадження в Україні $3000 \mathrm{TH}$, на які передбачено асигнування в обсязі, еквівалентному \$ 337,5 млн. Але в Україні відсутнє промислове виробництво теплових насосів. Маркетингові дослідження показали, що по системі ціна-якість найбільш ефективно використовувати теплові насоси китайського виробництва. Тому інститут співпрацює 3 партнерами КНР, які випускають промислові теплові насоси. Потужність таких ТН $0,5 \ldots 8,0$ МВт 3 температурою теплоносія $+70 \ldots+85{ }^{\circ} \mathrm{C}$. Питома вартість таких установок - біля 200 доларів США за 1 кВт встановленої потужності, що $є$ найнижчою з існуючих ринкових цін TH.

У разі використання китайських ТН тільки на опаленні можливо виробити кількість теплоти, достатньої для заміщення 1,35 млрд. м $^{3}$ газу за ціною 250 дол. США за $1000 \mathrm{~m}^{3}$ газу, або 2,65 млрд. м ${ }^{3}$ газу за ціною 127 доларів за $1000 \mathrm{~m}^{3}$ газу коли буде тільки гаряче водопостачання. Необхідна при цьому кількість електроенергії не перевищує 5,6 млрд. кВт·год на рік.

За оперативними даними НАК «Нафтогаз України» та ПАТ «Укртрансгаз» (без врахування зони АТО) в період 2013-2014 p.p. теплокомуненерго і бюджетні установи скоротили споживання газу за опалювальний

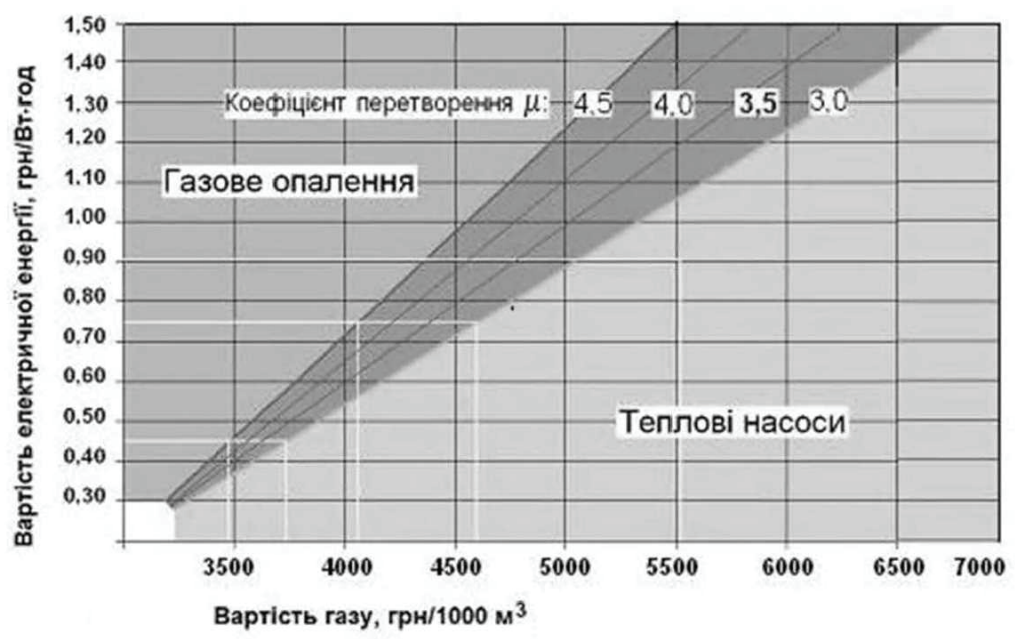

Рис. 6. Порівняльна вартість енергетичної складової теплоти, виробленоӥ за допомогою компресійного теплового насосу та при спалювання газу в котельні. 
період на 2,1 млрд. м $^{3}$ газу. Тому можна стверджувати, що Державна програма модернізації систем теплопостачання виконана на $50 \%$.

Сьогодні в світі 8..10 \% виробленої енергї витрачається на процеси сушіння, під час яких випаровується понад 25 млн. т вологи, що відноситься до парникових газів. Застосування ТН у процесах сушіння є досить ефективним. Як уже зазначалося, при використанні ТН для опалення чи гарячого водопостачання необхідно знайти джерело низькопотенційної енергії. У процесах сушіння воно є в самій сушарці. Це відпрацьований теплоносій, що традиційно викидається в атмосферу. Тобто використання теплонасосних установоку процесах сушіння - майже ідеальний варіант використання відпрацьованого в технологічному процесі сушіння теплоносія. За новою схемою відпрацьований теплоносій не викидається в атмосферу, а направляється у випарник з більш низькою температурою. При цьому його температура знижується, волога конденсується на поверхні випарника, віддаючи енергію конденсації робочому тілу. Сам теплоносій осушується. Далі він, проходячи через конденсатор, підвищує свою температуру i, суттєво осушений, знову подається у сушарку. При такій схемі волога не потрапляє в навколишнє середовище, а витрати енергії на процес сушіння суттєво знижуються у порівнянні з утрадиційними сушарками. У деяких випадках ці витрати становлять величину навіть меншу за теоретичну, необхідну для випаровування вологи з відкритої поверхні.

Вперше в Україні в ITТФ НАН України розроблено зерносушарку для насіннєвого зерна 3 використанням теплонасосної технології. Витрати енергії на випаровування вологи в ній становлять $0,6 \ldots 0,8$ кВт·год/л. Схожість зерна після сушіння - 100 \%. Сушарку впроваджено в МТС у Вінницькій області [7].

Інститут також розробив і впровадив у В'єтнамі технологічну лінію виробництва харчових порошків 3 тропічних фруктів (рис. 8). У цій лінії використано чотиризонну тунельну сушарку $з$ теплонасосною установкою. Це дозволило вперше в світі отримати натуральні харчові порошки з бананів та ананасів в умовах високої вологості тропічного клімату.

\begin{tabular}{|c|c|c|c|c|c|c|c|c|}
\hline \multicolumn{2}{|c|}{$\begin{array}{c}\text { Джерело } \\
\text { низькопотенщйної } \\
\text { енергіі }\end{array}$} & \multicolumn{2}{|c|}{$\begin{array}{c}\text { Потенціал } \\
\text { енергозбереження, } \\
\text { млн.ту. п. на рік }\end{array}$} & $\begin{array}{c}\text { Галузь } \\
\text { застосування }\end{array}$ & $\begin{array}{c}\text { Tипи тепловіх } \\
\text { насосів }\end{array}$ & $\begin{array}{c}\text { Оптимальн: } \\
\text { одинична } \\
\text { потужність. } \\
\text { кBT }\end{array}$ & \begin{tabular}{c|} 
Площа, яка \\
опалюсться \\
одиннцею \\
обладнання, \\
${\text { тис. }{ }^{2}}^{2}$
\end{tabular} & 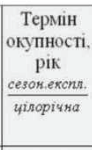 \\
\hline & $\begin{array}{l}\text { Водообігові цикли } \\
\text { в енергетпші і } \\
\text { промнсловості }\end{array}$ & 25.0 & 2.5 & \multirow{4}{*}{$\begin{array}{l}\text { Комунальне } \\
\text { жштло, } \\
\text { промпслові } \\
\text { об єкти }\end{array}$} & $\begin{array}{l}\text { компресійннй, } \\
\text { абсорбційннй }\end{array}$ & $5 \cdot 10^{3}$ & 50 & $\frac{5-8}{3-5}$ \\
\hline & $\begin{array}{l}\text { Геотермальна } \\
\text { енергія }\end{array}$ & 12,0 & 9,3 & & \multirow[t]{2}{*}{$\begin{array}{l}\text { компресійний, } \\
\text { абсорбційний }\end{array}$} & $200 \div 1000$ & $2 \div 10$ & $\frac{5-8}{3-5}$ \\
\hline & Стічғі води & 8,5 & 1,6 & & & $100 \div 1000$ & $10 \div 50$ & $3-4,5$ \\
\hline & Шахтні води & 1,4 & 0,8 & & $\begin{array}{l}\text { компресійний, } \\
\text { абссорбційннй }\end{array}$ & $100 \div 1000$ & $10 \div 50$ & $3-4,5$ \\
\hline & $\begin{array}{l}\text { Верхній шар } \\
\text { грунту }\end{array}$ & 9.0 & 1,1 & \multirow{4}{*}{$\begin{array}{c}\text { Індивідуальне } \\
\text { i комунальне } \\
\text { житло }\end{array}$} & \multirow{2}{*}{ компресійний } & $5 \div 100$ & $0,05 \div 1,0$ & $\frac{4-5}{2-3}$ \\
\hline & $\begin{array}{l}\text { Tепло відқритгх } \\
\text { водоймпщи }\end{array}$ & 14,0 & 5,0 & & & $10 \div 100$ & $0.1 \div 1.0$ & $\frac{4-5}{2-3}$ \\
\hline & $\begin{array}{l}\text { Вентилацийні } \\
\text { Викнди }\end{array}$ & 0,8 & 0.25 & & компресійннй & $5 \div 80$ & $0.05 \div 0.8$ & $\frac{2-3}{1,5-2}$ \\
\hline & Сонятна енергія & необмме ж. & 6,0 & & компресійний & $5 \div 80$ & $0.05 \div 0.2$ & $\frac{5-8}{3-4}$ \\
\hline & \multicolumn{2}{|c|}{ Bcboro: } & 26,55 & \multicolumn{5}{|c|}{$\begin{array}{c}\text { Перспективи заощадження } \\
\text { природного газу - } 20 \text { млрд. } \text { м }^{3}\end{array}$} \\
\hline
\end{tabular}

Рис. 7. Порівняльна вартість енергетичної складової теплоти, виробленої за допомогою компресійного теплового насос,у та при спалюванні природного газу в котельні.

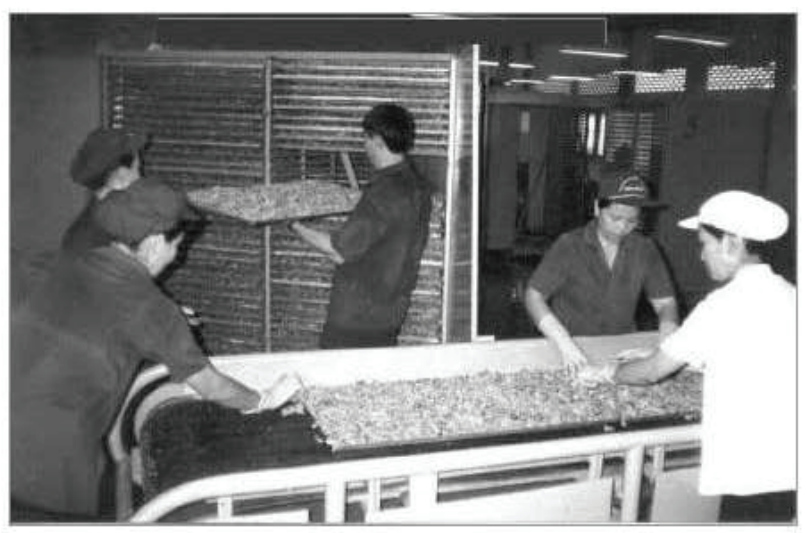

Рис. 8. Технологічна лінія виробництва харчових порошків з тропічних фруктів. 
Створена в Інституті камерна теплонасосна сушарка для зневоднення харчових продуктів дає змогу отримувати високоякісну термолабільну харчову сировину. За допомогою цієї сушарки фахівці ІТТФ НАН України розробили близько 30 видів сухих пайків для гарячого харчування військовослужбовців, які були успішно апробовані в бойових умовах АТО.

Потенціал енергозбереження в процесах сушіння в різних галузях промисловості України оцінюється в 1,6...2,1 млн. т у.п. на рік. Найбільшим він є в процесі сушіння будівельних матеріалів, вугілля, зерна i пиломатеріалів. Використання ТН у цих технологічних процесах може заощадити майже 1 млрд. м $^{3}$ газу.

\section{Висновки}

- Загальний потенціал енергозбереження в Україні від впровадження теплонасосних технологій - 26 млн. т у.п. на рік, що дозволяє заощадити близько 20 млрд. м $^{3}$ газу. Технічно досяжний потенціал енергозбереження біля 11 млн. т у.п., що дорівнює понад 8,4 млрд. м³ газу на рік, економічно досяжний - біля 6,5 млн. т у.п., що еквівалентно 5 млрд. м ${ }^{3}$ газу.

- Ефективність впровадження теплотехнологій необхідно оцінювати не за тарифами на теплову енергію, а за обсягами економії природного газу.

- Варто надавати преференції покупцям тепло- вих насосів (часткова грошова компенсація державою, пільговий кредит, відшкодування процентної ставки за кредитом тощо).

- Доцільно розробити програму організації виробництва вітчизняних теплових насосів.

\section{ЛИТЕРАТУРА}

1. Энергоэффективность как ресурс инновационного развития: Национальный доклад о состоянии и перспективах реализации государственной политики энергоэффективности в 2008 году. К.: НАЕР, 2009.

2. Экопортал www.envizonments.land-ecology. com.ua

3. Атлас энергетического потенциила возобновляемых и нетрадиционных источников. К., 2005.

4. Кудря C.A. Нетрадиционные и возобновляемые источники энергии:учебн. / Кудря С.А. - К.: НТУУ «КПИ», 2012. - 492 с.

5. Рынок теплових насосов в ЕС. Холод. 2010. N2. C.14-19

6. Шведские тепловые насосы ОСТОРUS www.octopus.ua

7. Снежкин Ю.Ф., Петрова Ж.А., Пазюк В.М. Энергоэффективные теплотехнологии производства функциональных пищевых порошков. Монография. Винница: «ВНАУ», 2016. - 456 с.
ENERGY EFFICIENT HEAT PUMP TECHNOLOGY. STATUS AND PROSPECTS OF THEIR INTRODUCTION IN UKRAINE

\section{Sniezhkin Yu.F.}

Institute of Engineering Thermophysics of the National Academy of Sciences of Ukraine, vul. Zhelyabova, 2a, Kyiv, 03680, Ukraine

In the article addresses issues the state, development and implementation of heat pump technology in Ukraine. Examples use of these technologies both in the world and in Ukraine. Presented various schemes using of heat pump technology in field of housing economy and industry. Shown volume are possible economy of power resources in a wide implementation of heat pump technology.

1. Energy efficiency as a resource innovative development. http://esco.co.ua/journal/2012_6/art356.pdf

2. Ecoportal www.envizonments.land-ecology.com. ua

3. Atlas of the Energy Potential of Renewable and Alternative Sources. (Kyiv, 2005). http://www.intelcenter. com.ua/rus/Cibrary/atlas alten ua.htm.

4. Kudria S.O. Āternative and renewable energy sources: textbook/ S.O. Kudria. - K.:NTUU "KPI", 2012. $492 \mathrm{p}$.

5. Heat pumps market in the EU. Khold.2010.2:14-19

6. Swedish Heat Pumps OCTOPUS. www.octopus.ua

7. Sniezhkin Yu.F., Petrova Zh.O., Paziuk V.M. Energy efficient heat technology of production functional food powders: monograph - Vinnytsia: "VNAU", 2016. $456 \mathrm{p}$.

Получено 22.03.2017 Received 22.03.2017 